\title{
The incidence of penetrating trauma in London: have previously reported increases persisted in the last six years?
}

\author{
Kate Crewdson*, Anne E Weaver, Gareth E Davies, David J Lockey \\ From London Trauma Conference 2013 \\ London, UK. 10-13 December 2013
}

\section{Background}

We have previously reported a $20.5 \%$ annual rise in penetrating trauma attended by our pre-hospital trauma service between 1991 and 2006. Data from national registries was conflicting and surprisingly difficult to obtain. We established an increasing trend and predicted a continued rise. This study was performed to establish whether this prediction was correct. Rising penetrating trauma rates have implications for emergency medical care provision and policing.

\section{Method}

A retrospective review of the London Air Ambulance database was conducted to identify patients who sustained deliberate penetrating trauma from January $1^{\text {st }}$ 2007 to December $31^{\text {st }} 2012$. Children, and patients who died in the pre-hospital phase were included. The number of pre-hospital resuscitative thoracotomies performed by the service was also recorded.

\section{Results}

The median number of penetrating trauma cases attended per year was 95, (range 14-220) in the period 1991-2006, and 352.5, (range 205-416) from 2007 to 2012. These figures represent $9.9 \%$ and $19.3 \%$ of the annual trauma caseload respectively. The mean increase per annum was $20.5 \%$ in the initial study, which equates to a mean increase of 10.3 cases per year $(R=0.89)$ over the 16 years, and $14 \%$ in the follow-up study, equivalent to 32.7 cases per year $(R=0.81)$. The corresponding increase in blunt trauma of $1.9 \%, 30.8$ cases per year $(R=0.86)$ from 1991-2006, and 8.9\% per year or 75.2 cases / year

London's Air Ambulance, Royal London Hospital, London, E1 1BB, UK
( $\mathrm{R}=0.84$ ) between 2007-2012, was less than that observed for penetrating trauma $(\mathrm{p}<0.0001)$.

There was a corresponding rise in the number of prehospital thoracotomies performed in the same period.

\section{Conclusion}

The rise in penetrating trauma that we reported in our pre-hospital trauma service in the period 1991-2006 has continued to rise in the period 2007-2013. This has considerable impact on the provision of trauma services and policing.

Published: 7 July 2014

\section{doi:10.1186/1757-7241-22-S1-P3}

Cite this article as: Crewdson et al:: The incidence of penetrating

trauma in London: have previously reported increases persisted in the

last six years? Scandinavian Journal of Trauma, Resuscitation and Emergency Medicine 2014 22(Suppl 1):P3.

Submit your next manuscript to BioMed Central and take full advantage of:

- Convenient online submission

- Thorough peer review

- No space constraints or color figure charges

- Immediate publication on acceptance

- Inclusion in PubMed, CAS, Scopus and Google Scholar

- Research which is freely available for redistribution 